\title{
Martyrdom in Islam. Cambridge/New York/ Melbourne, Cambridge University Press, 2007, 206 p. (Themes in Islamic History, 4)
}

Ève Feuillebois-Piérunek

\section{(2) OpenEdition}

1 Journals

\section{Édition électronique}

URL : http://journals.openedition.org/abstractairanica/39702

DOI : 10.4000/abstractairanica.39702

ISSN : 1961-960X

Éditeur :

CNRS (UMR 7528 Mondes iraniens et indiens), Éditions de l'IFRI

\section{Édition imprimée}

Date de publication : 15 mai 2011

ISSN : 0240-8910

\section{Référence électronique}

Ėve Feuillebois-Piérunek, « Martyrdom in Islam. Cambridge/New York/Melbourne, Cambridge University Press, 2007, 206 p. (Themes in Islamic History, 4) », Abstracta Iranica [En ligne], Volume 31 | 2011 , document 233, mis en ligne le 11 octobre 2012, consulté le 27 septembre 2020. URL : http:// journals.openedition.org/abstractairanica/39702 ; DOI : https://doi.org/10.4000/abstractairanica. 39702

Ce document a été généré automatiquement le 27 septembre 2020.

Tous droits réservés 


\title{
Martyrdom in Islam. Cambridge/New York/Melbourne, Cambridge University Press, 2007, 206 p. (Themes in Islamic History, 4)
}

\author{
Ève Feuillebois-Piérunek
}

Le martyre en islam a été récemment associé aux attentats suicides. D. C. montre que ce type d'attitude est radicalement éloigné de la définition classique du martyre qui condamne le suicide et attribue le statut de martyr à toute personne morte en musulmane. La définition du martyre en Islam a évolué dans l'histoire en fonction des circonstances. Le livre s'intéresse aux premières discussions sur le martyre, aux définitions légales et aux récompenses accordées aux martyrs, aux différences de compréhension de cette notion chez les sunnites, les shi'ites, et les soufis, aux martyrs guerriers ou missionnaires de l'islam médiéval, aux martyrs d'amour et aux héros épiques, au martyre dans l'islam radical contemporain. C'est le premier ouvrage à traiter de ce thème de manière aussi complète et documentée. L'essai de comparaison avec d'autres traditions religieuses (judaïsme et christianisme) rend l'ouvrage plus accessible aux non spécialistes et aux non musulmans.

\section{INDEX}

Thèmes : 7. Islam 
AUTEURS

ÈVE FEUILLEBOIS-PIÉRUNEK

Université Sorbonne Nouvelle - Paris 3 - Mondes iranien et indien 